\title{
Desain Perbaikan Kualitas Produk Keramik Melalui Six Sigma Dan Flexsim Di PT. XYZ
}

\author{
Lazuardy Reza Syahputra' ${ }^{1}$ dan Lukmandono ${ }^{2}$ \\ ${ }^{1,2}$ Magister Teknik Indusstri, Institut Adhi Tama Surabaya, Jalan Arief Rahman Hakim No.100, Surabaya, \\ Indonesia, 60117 \\ Correspondence: lazuardyreza07@gmail.com \\ 085755535514
}

Received: 150721 - Revised: 090821 - Accepted: 100821 - Published: 150821

\begin{abstract}
Abstrak. Persaingan industri manufaktur di Indonesia semakin ketat. PT.XYZ adalah perusahaan pionir di Indonesia untuk memproduksi keramik. Penelitian ini dilakukan yang bertujuan untuk mengurangi jumlah defect dengan menggunakan metode six sigma dan software flexsim. Berdasarkan data, kumulatif defect terjadi pada bulan Oktober tahun 2020 yaitu sebesar 57.632 pcs dengan presentase defect sebesar 20,39\% dan jumlah defect terendah yang terjadi pada bulan November sebesar 35.372 pcs presentase defect sebesar 12,51\%. Sedangkan untuk jenis defect yang paling tinggi pada produk keramik yaitu pada Retak Body sebesar 64.069 pcs dengan presentase defect sebesar 23,05\% dan jenis defect terendah yang terjadi pada ukuran sebesar 19.530 pcs presentase defect sebesar 7,03\%. Nilai rata-rata DPMO yang didapat yaitu sebesar 7571 dan nilai rata-rata sigma yang didapat sebesar 3,93. Berdasarkan hasil simulasi flexsim didapat penggantian operator pada bagian mesin sortir sehingga lebih efektif dalam hal beban kerja dan efisien waktu. Pada mesin packing hasil output disimulasikan 20 pcs. rata-rata staytime sebesar 5.0 dan pada mesin sortir hasil output disimulasikan 20 pcs dan rata-rata staytime sebesar 8.89 .
\end{abstract}

Kata kunci: Defect, Six Sigma, Flexsim

Citation Format: Syahputra, L.R., Lukmandono. (2021). Desain Perbaikan Kualitas Produk Keramik Melalui Six Sigma Dan Flexsim Di PT. XYZ, 2021, 01-08. 


\section{PENDAHULUAN}

Di Indonesia, banyak orang menyadari pentingnya kualitas pada pelanggan yang terus berubah. Persaingan industri saat ini yang semakin ketat, perusahaan harus mampu bertahan dan bersaing dengan perusahaan sejenis. Bagi industri manufaktur saat ini perubahanperubahan yang terjadi seperti perubahan teknologi adalah tantangan yang harus dihadapi dan menuju system manufaktur yang lebih maju dari system sebelumnya (Lukmandono et.al, 2020). Oleh karena itu, perusahaan harus melihat dan menjaga agar kualitas produk yang dihasilkannya terjamin dan diterima konsumen, serta dapat bersaing di pasar. Pengendalian mutu yang diterapkan dengan benar akan berdampak pada kualitas produk perusahaan. Kualitas adalah seluruh atribut karakteristik produk atau jasa yang meliputi berbagai bidang seperti pemasaran, teknik, manufaktur, dan perbaikan, produk dan jasa tersebut dalam kegunaannya akan sesuai dengan kebutuhan dan keinginan pelanggan. (Sinatra et.al, 2017).

Pada proses produksi dapat menghasilkan produk yang tidak memenuhi standar atau kriteria yang sudah ditentukan oleh suatu departemen kualitas dalam suatu perusahaan. Produk yang tidak memenuhi kriteria tersebut dapat dikatakan sebagai produk defect yang tidak dapat langsung didistribusikan ke pasar. Perbaikan tersebut menimbulkan biaya baru yang diklasifikasikan sebagai biaya kualitas. Adanya produk defect tersebut berimbas terhadap finance perusahaan. (Oktavianus dan Caesaron,2017)

Six Sigma merupakan metode yang dapat menyelesaikan masalah dan memperbaiki proses dengan cara mengurangi cacat dan tahap perbedaan yang dilakukan pada tahap definisi, tahap pengukuran, tahap analisis, tahap perbaikan dan tahap kontrol. Langkah ini disebut metode DMAIC. Tahap analisis merupakan tahap ketiga dari rangkaian proses Six Sigma DMAIC. Tahapan ini diselesaikan dengan menganalisis faktor-faktor yang mempengaruhi cacat produk dan alasan utamanya, sehingga dapat dilakukan perbaikan data yang dihasilkan dari penelitian ini merangkum persentase kecacatan yang terjadi pada tempat sesuai standar jenis cacat, kemudian mengkorelasikannya dengan urutan jumlah cacat tertinggi sesuai proses produksi. Hasilnya adalah memprioritaskan perbaikan berdasarkan tingkat kerusakan total tertinggi (Imam et al. 2020).

Peneliti menggunakan software flexsim untuk simulasi. Flexsim adalah perangkat lunak simulasi diskrit untuk pemodelan dan mensimulasikan sistem yang berbeda dari beberapa industri yang berbeda. Perangkat lunak Flexsim apakah teknologi komputer 3D, itu adalah teknologi simulasi, teknologi cerdas teknologi pemrosesan manual dan data. Flexsim cocok untuk pembuatan, penyimpanan dan transportasi, sistem transportasi dan 
bidang lainnya. (Zhu et al., 2014). Flexsim memiliki hampir semua objek fisik yang ada seperti prosesor, operator, ban berjalan, forklift, lampu lalu lintas, tangki bahan bakar, rak, penumpuk otomatis, dll. Selain itu, Flexsim juga menyediakan fitting data mentah, input pemodelan, konstruksi model grafis, jalankan model, optimalkan hasil, dan buat file untuk eksperimen simulasi (Li-Hong et al., 2013).

\section{MASALAH}

Diketahui bahwa hasil proses produksi keramik pada bulan Agustus 2020-Januari 2021 permasalahan di lapangan, PT. XYZ pada total produksi paling tinggi terjadi pada bulan Desember dengan total produksi sebesar 96742 dan peresentase defect tertinngi terjadi pada bulan Oktober sebesar $6.13 \%$, bahwa total produksi yang masih fluktuatif dan persentase kecacatan yang masih tinggi mencapai $6.13 \%$ dan diketahui bahwa jenis defect keramik pada bulan Agustus 2020-Desember 2021 permasalahan di lapangan PT. XYZ dengan defect yang sering terjadi adalah jenis retak bodi dengan jumlah defect sebesar 64069 dengan persentase sebesar $23 \%$ dari total cacat yang dihasilkan.

\section{METODE PELAKSANAAN}

Untuk menyelesaikan permasalahan penelitian ini yaitu mengukur kualitas produk keramik dan mensimulasikan hasil improvement yang digunakan pada suatu kegiatan proses produksi untuk mengetahui kualitas hasil proses produksi dalam periode tertentu. Penelitian ini dilakukan di salah satu perusahaan keramik.

\section{HASIL DAN PEMBAHASAN}

Dalam penelitian ini penerapan pengendalian kualitas yang digunakan adalah dengan metode Six Sigma berfokus pada pendekatan DMAIC yang tahapannya dimulai dengan proses define, measure, analyze, improve dan control. Fokus observasi pada penelitian ini dilakukan pada bagian produksi. Analisis hasil penelitian menggunakan metode six sigma dengan DMAIC pada PT. XYZ sebagai berikut :

\section{Define}

Produk keramik yang dianalisis berdasasarkan jenis-jenis kecacatan menggunakan data produksi periode Agustus 2020 - Januari 2021. Berikut adalah data produksi dan jumlah defect untuk periode Agustus 2020 - Januari 2021 :

\section{Data Total Produksi \& Persentase Defect}

Total Produksi (Pcs) $\quad$ Persentase Defect (\%) 
Diketahui bahwa hasil proses produksi keramik pada bulan Agustus 2020-Januari 2021 permasalahan di lapangan, PT. XYZ pada total produksi paling tinggi terjadi pada bulan Desember dengan total produksi sebesar 96742 dan peresentase defect tertinngi terjadi pada bulan Oktober sebesar $6.13 \%$, bahwa Total produksi yang masih fluktuatif dan persentase kecacatan yang masih tinggi mencapai $6.13 \%$

\section{Measure}

Berdasarkan hasil pengolahan data pada PT XYZ untuk menyusun CTQ diperlukan identifikasi permasalahan defect pada keramik yang diproduksi. Berikut adalah data jenis defect produk keramik pada bulan Agustus 2020 - Januari 2021.

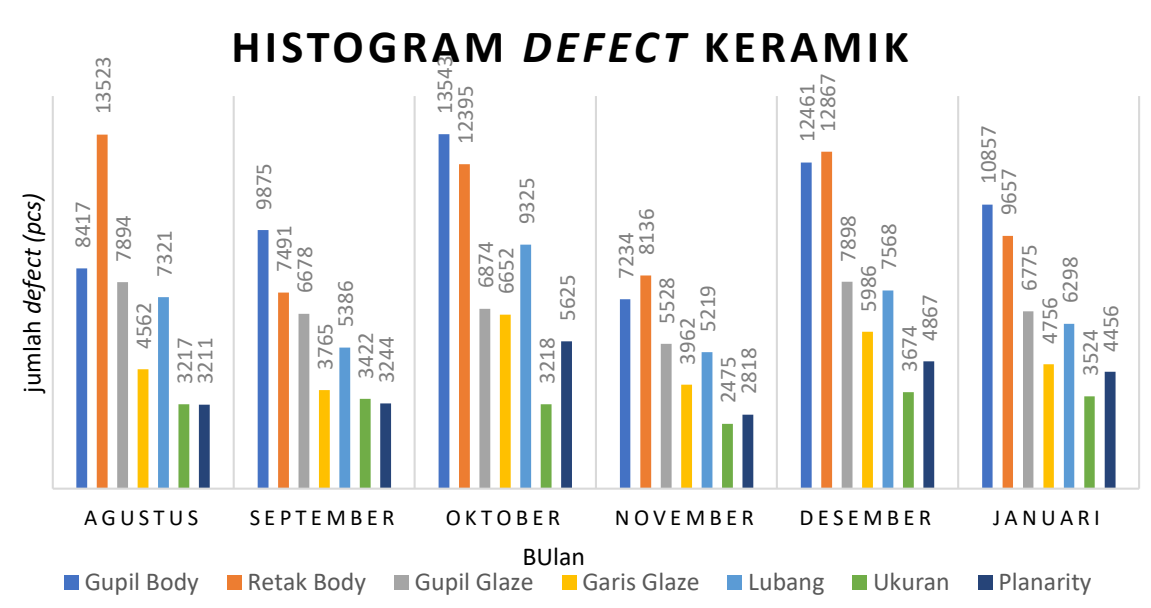

Gambar 2. Diagram Pareto Defect Pada Produk Keramik Bulan Agustus-Januari 2021

Dari gambar histogram diatas dapat dilihat bahwa jumlah defect yang terjadi pada produk keramik pada bulan Agustus 2020 - Januari 2021 terkadang mengalami peningkatan dan terkadang mengalami penurunan.

Defect keramik bulan Agustus 2020-Desember 2021

60000,0

50000,0

40000,0

30000,0 
Gambar 3. Diagram Pareto Defect Pada Produk Keramik Bulan Agustus-Januari 2021

Dari diagram pareto di atas, periode kecatatan paling banyak adalah pada Bulan Oktober dengan jumlah defect sebesar 57632 Pcs dan persentase kumulatif dari total kecacatan adalah $20,39 \%$

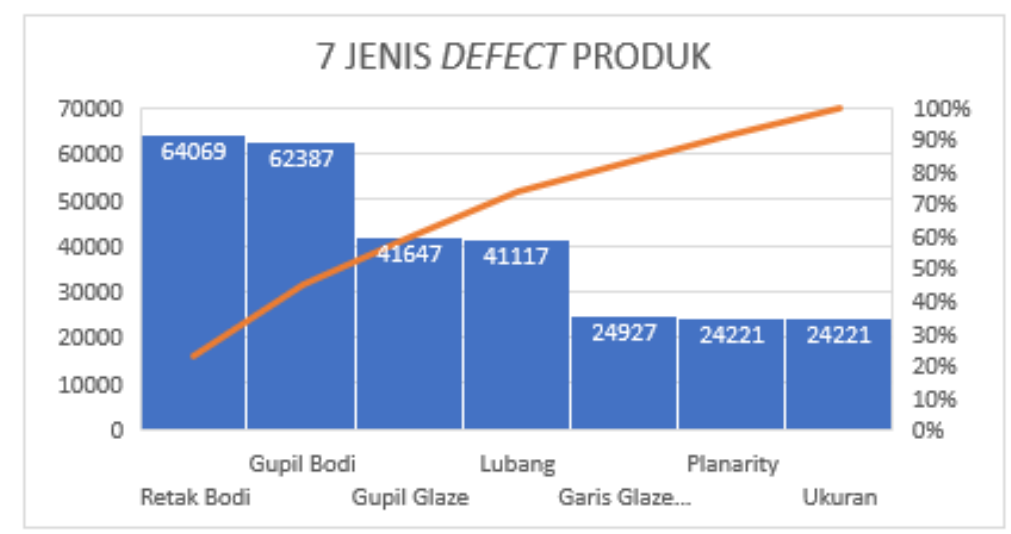

Gambar 4. Diagram Pareto7 Jenis Defect Produk

Dari diagram pareto di atas, jenis defect atau kecatatan paling banyak adalah pada retak bodi dengan jumlah sebesar 64069 Pcs dan persentase kumulatif dari total kecacatan adalah $23,05 \%$.

Langkah selanjutnya dapat dilakukan perhitungan nilai DPMO dan nilai sigma. Pada sub pokok bahasan mengenai $C T Q$ telah disebutkan bahwa banyaknya $C T Q$ Potensial atau karakteristik kualitas yang menyebabkan kecacatan adalah sebanyak 7. Dimana 7 CTQ tersebut merupakan cacat keramik yang paling sering terjadi.

$$
D P M O=\frac{\text { Cacat }}{\text { Banyak Unit yang diperiksa } \times C T Q} \times 1.000 .000
$$


Untuk perhitungan Sigma Level atau nilai Sigma dilakukan dengan menggunakan Microsoft Excel, maka perhitungan nilai Sigma dapat dilakukan dengan memasukkan rumus:

$$
=\text { normsinv }((1000000-\mathrm{DPMO}) / 1000000)+1.5
$$

\section{Analyze}

Diagram sebab akibat memperlihatkan hubungan antara permasalahan yang dihadapi dengan kemungkinan penyebabnya serta faktor-faktor yang mempengaruhinya. Adapun faktor-faktor yang mempengaruhi dan menjadi penyebab untuk jenis defect retak bodi, sebagai berikut:

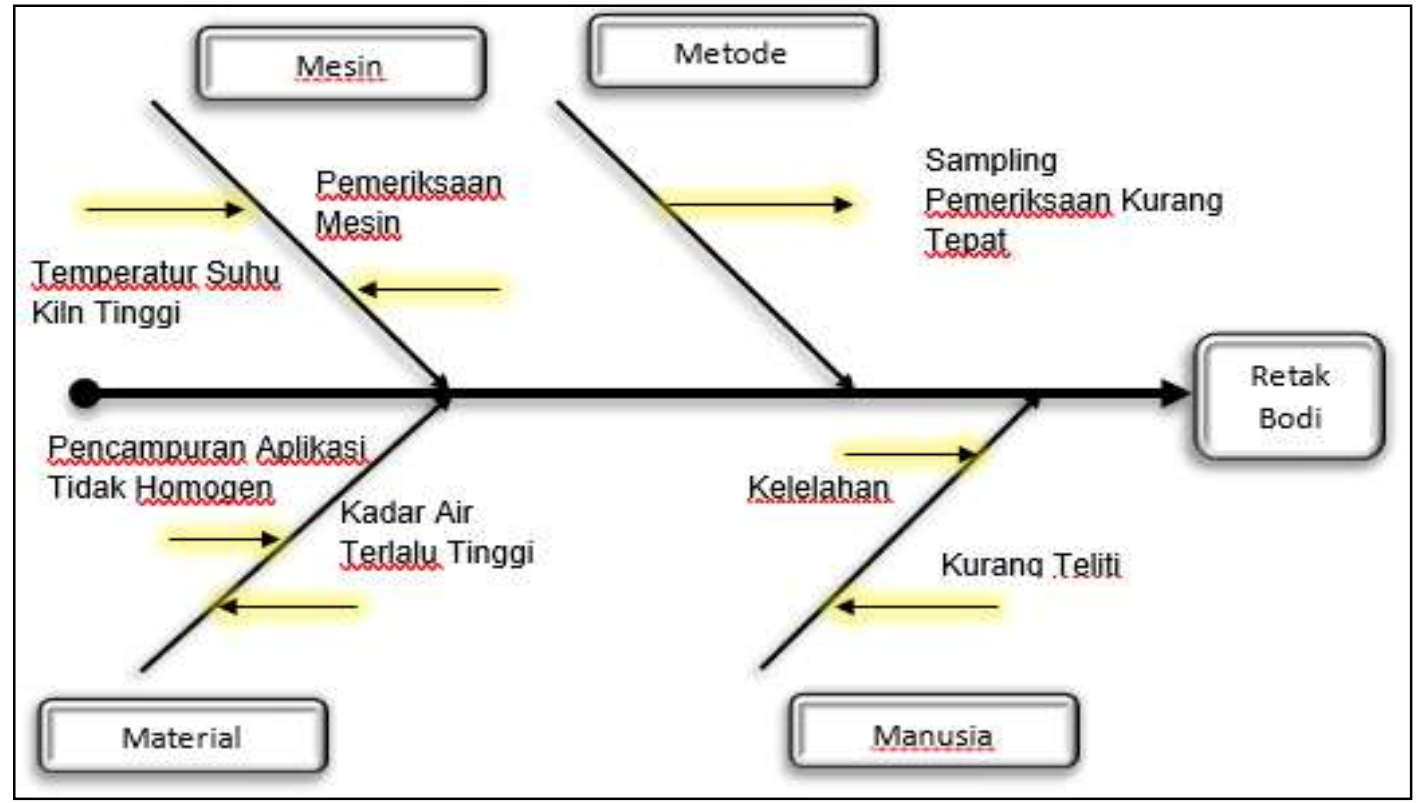

Gambar 5. Fishbone Diagram Retak Bodi

\section{Control}

Merupakan tahap analisis terakhir dari proyek six sigma yang menekankan pada pendokumentasian dan penyebarluasan dari tindakan yang telah dilakukan.

\section{Simulasi Flexsim}

Model Awal Perusahaan menggunakan simulasi flexsim dalam 1 line produksi, adalah sebagai berikut : 


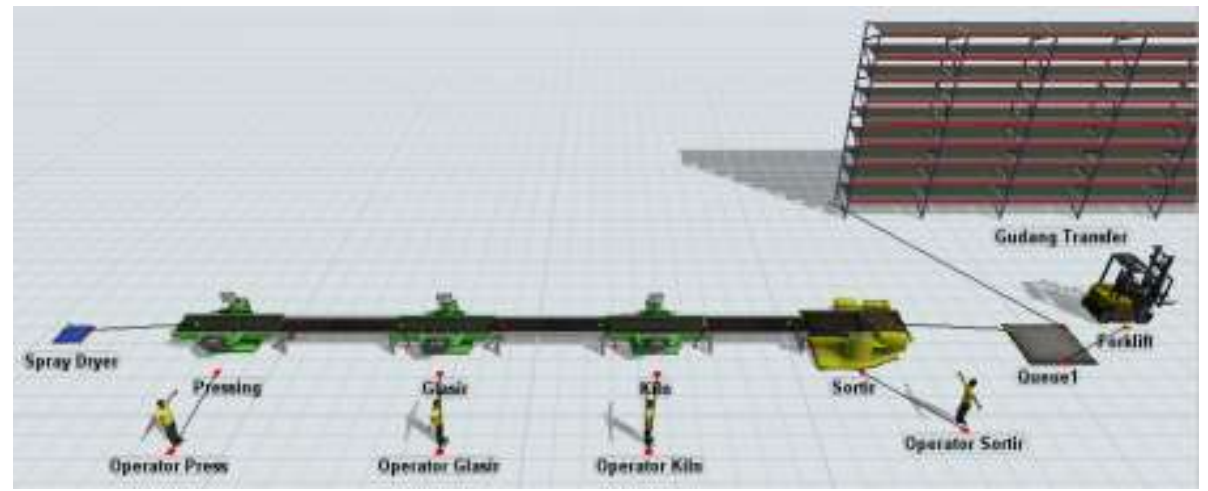

Gambar 6. Model Awal Perusahaan Menggunakan Simulasi Flexsim

Dari gambar 6 diatas di dapat bahwa untuk hasil output disimulasikan 20 pes dan rata-rata staytime sebesar 11.19. Tahapan selanjutnya yaitu membuat usulan model simulasi menggunakan software flexsim dengan memberikan saran dan improvement berdasarkan implementasi DMAIC. Tahapan selanjutnya yaitu menganalisis model dan melakukan desain eksperimen improvement

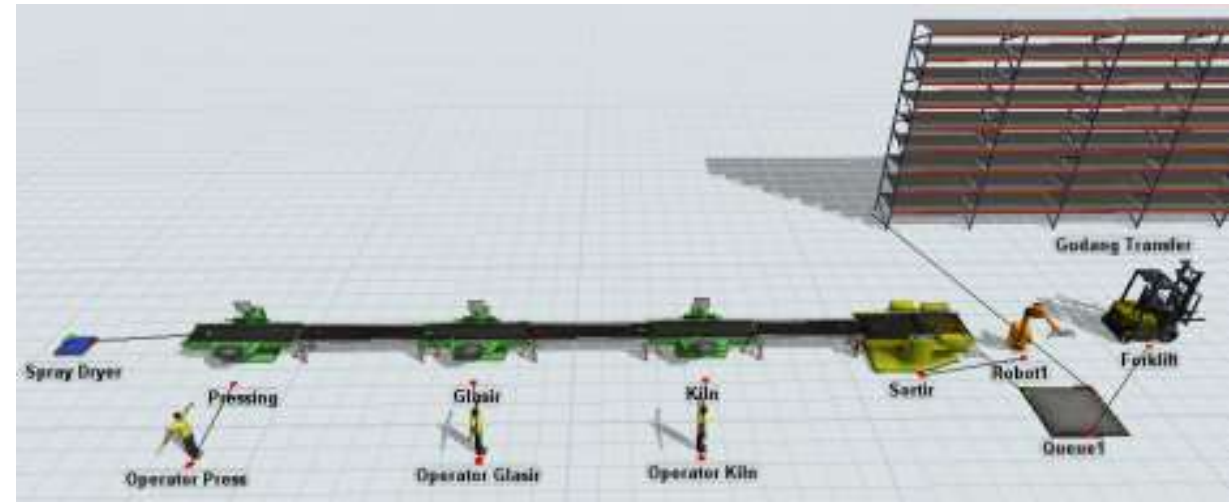

Gambar 7. Model Awal Perusahaan Menggunakan Simulasi Flexsim

Dari gambar 7 diatas di dapat bahwa untuk hasil output disimulasikan 20 pes dan rata-rata staytime sebesar 8.89

\section{KESIMPULAN}

Hasil pengukuran kualitas produk keramik pada PT. XYZ defect pada produk terjadi pada bulan Oktober tahun 2020 yaitu sebesar 57.632 pcs dengan presentase defect sebesar 20,39\% dan jumlah defect terendah yang terjadi pada bulan November tahun 2020 sebesar 35.372 pcs presentase defect sebesar $12,51 \%$. Sedangkan untuk jenis defect yang paling tinggi pada produk keramik yaitu pada retak body sebesar 64.069 pcs dengan presentase 
defect sebesar 23,05\% dan jenis defect terendah yang terjadi pada ukuran sebesar $19.530 \mathrm{pcs}$ presentase defect sebesar 7,03\%. Nilai rata - rata DPMO yang didapat yaitu sebesar 7.571 dan nilai rata-rata Sigma yang didapat sebesar 3,93.

Berdasarkan hasil simulasi flexsim didapat penggantian operator pada bagian mesin sortir sehingga lebih efektif dalam hal beban kerja dan efisien waktu. Pada mesin packing hasil output disimulasikan 20 pcs. Rata-rata staytime sebesar 5.0 dan pada mesin sortir hasil output disimulasikan 20 pcs dan rata-rata staytime sebesar 8.89

\section{UCAPAN TERIMA KASIH}

Untuk para staff dan jajaran pegawai di PT.XYZ yang sudah banyak meluangkan waktu dan tenaga untuk membantu menyelesaikan Tesis ini saya mengucapakan banyak terima kasih.

\section{DAFTAR PUSTAKA}

Imam,S., \& Prastiwinarti, W. (2020). Analisis Tingkat Kecacatan Produk Cetak Kemasan Karton Lipat Dengan Pendekatan DMAIC Six Sigma. Jurnal Poli-Teknologi, 19(2), 161-168.

Lukmandono, L., Sulistyowati, E., \& Hariastuti, N. L. P. (2020). Pendekatan Overall Equipment Effectiveness Dan Response Surface Methodology Dengan Pertimbangan Root Cause Failure Analysis Untuk Meminimalkan Six Big LOSSES. Katalog Buku Karya Dosen ITATS, 70-112.

Oktavianus, W., \& Caesaron, D. (2017). Analisis Pengendalian Kualitas Cacat dengan Metode Six Sigma pada Perusahaan Percetakan (Studi Kasus: PT. Delta Mandiri). Journal of Industrial Engineering and Management Systems, 9(1).

Sinatra, O. B., Narto, N., \& Lukmandono, L. (2017). Implementasi Six Sigma Sebagai Upaya Untuk Meningkatkan Produktivitas. Prosiding SNST Fakultas Teknik, 1(1).

Zhao, X. (2010, May). A method of product quality cooperation management based on holonic. In 2010 The 2nd International Conference on Industrial Mechatronics and Automation (Vol. 2, pp. 368-371). IEEE.

Zhu, X., Zhang, R., Chu, F., He, Z., \& Li, J. (2014). A Flexsim-based Optimization for the Operation Process of ColdChain Logistics Distribution Centre. Journal of Applied Research and Technology, 27. 